\title{
PERBANDINGAN ANALISIS PERKUATAN STRUKTUR PELAT DENGAN METODE ELEMEN HINGGA
}

\author{
Samuel Agustinus, Cindrawaty Lesmana \\ Program Studi Teknik Sipil, Universitas Kristen Maranatha \\ Jalan Prof. drg. Surya Sumantri, MPH, No. 65, Bandung, 40164
}

\begin{abstract}
ABSTRAK
Kerusakan pada bangunan disebabkan karena beberapa hal, di antaranya: salah perhitungan atau salah perencanaan awal, bencana alam, perubahan fungsi ruang, dan sebagainya. Jika kerusakan struktur telah terjadi, maka perlu perbaikan atau perkuatan sesuai dengan kerusakannya, begitupun pada pelat lantai. Perkuatan pada pelat lantai mempunyai beberapa solusi, yaitu menggunakan FRP, menambah tebal pelat, dan sebagainya. Memilih perkuatan pelat yang efektif memerlukan beberapa pertimbangan, antara lain: seberapa besar pengaruh perkuatan yang dilakukan, biaya perkuatan, waktu pekerjaan, dan metode pelaksanaan pekerjaan. Analisis yang dilakukan untuk mengetahui seberapa besar pengaruh perkuatan pelat adalah dengan metode elemen hingga (MEH). Analisis membutuhkan data lengkap, seperti dimensi pelat, tebal pelat, mutu beton, diameter tulangan, jenis tulangan, dan spasi antar tulangan. Untuk memperoleh data tersebut dibutuhkan investigasi dan uji lapangan. Setelah dilakukan analisis perkuatan pelat, lalu dilakukan analisis biaya perkuatan, waktu pekerjaan, dan metode pelaksanaan pekerjaan untuk mendapatkan jenis perkuatan yang efektif. Tujuan penelitian adalah membandingkan antara perkuatan struktur pelat menggunakan FRP dan memperkecil bentang pelat dengan menggunakan balok IWF. Pertimbangan dilakukan berdasarkan hasil analisis MEH, biaya perkuatan, waktu pekerjaan, dan metode pelaksanaan pekerjaan. Hasil analisis, menyatakan bahwa pelat lantai dengan menggunakan perkuatan FRP, baik model satu, dua, dan tiga, memiliki displacement dan tegangan lebih baik daripada menggunakan balok IWF, namun biaya perkuatan dengan FRP model satu, dan dua lebih mahal dibandingkan dengan menggunakan FRP model tiga dan IWF.
\end{abstract}

Kata Kunci: pelat lantai, analisis $\mathrm{MEH}$, biaya perkuatan, waktu pekerjaan, metode pelaksanaan pekerjaan.

\begin{abstract}
Damage to buildings is caused by several things, including: miscalculation or incorrect initial design, natural disasters, changes in space functions, and so on. If structural damage has occurred, it is necessary to repair or strengthen according to the damage, as well as on the floor slab. The reinforcement on the floor slab has several solutions, namely using FRP, increasing the thickness of the slab, and so on. Choosing an effective slab reinforcement requires several considerations, including: how much influence is strengthened, strengthening costs, time of work, and method of carrying out the work. The analysis carried out to determine how much the effect of slab reinforcement is by the finite element method $(M E H)$. Analysis requires complete data, such as slab dimensions, slab thickness, concrete quality, reinforcement diameter, reinforcement type, and spacing between reinforcement. To obtain the data, investigation and field testing are needed. After the slab reinforcement analysis is carried out, an analysis of strengthening costs, time of work, and method of carrying out the work is carried out to obtain an effective type of reinforcement. The aim of the study was to compare the reinforcement of the slab structure using FRP and reduce the slab span using the IWF beam. Consideration is based on the results of the MEH analysis, strengthening costs, time of work, and method of carrying out the work. The results of the analysis stated that the floor slab using FRP reinforcement, both models one, two, and three, had better displacement and stress than using the IWF beam, but the reinforcement costs with FRP model one, and two were more expensive than using FRP model three and IWF.
\end{abstract}

Keywords: floor slab, MEH analysis, reinforcement costs, work time, method work implementation

Perbandingan Analisis Perkuatan Struktur Pelat Dengan Metode Elemen Hingga 


\section{PENDAHULUAN}

Konstruksi merupakan suatu kegiatan membangun sarana maupun prasarana. Dalam bidang Arsitektur atau Teknik Sipil, sebuah konstruksi dikenal sebagai bangunan atau satuan infrastruktur pada sebuah area atau pada beberapa area. Secara ringkas konstruksi didefinisikan sebagai objek keseluruhan bangunan yang terdiri dari bagianbagian struktur (Mulyono, D., 2014). Struktur bangunan pada umumnya terdiri dari struktur bawah (lower structure) dan struktur atas (upper structure). Struktur bawah adalah pondasi dan struktur bangunan yang berada di bawah permukaan tanah, sedangkan struktur atas adalah struktur bangunan yang berada di atas permukaan tanah seperti kolom, balok, pelat, dan tangga. Setiap komponen memiliki fungsi yang berbeda-beda di dalam sebuah struktur. Suatu bangunan gedung beton bertulang yang memiliki banyak lantai, sangat rawan terhadap keruntuhan jika tidak direncanakan dengan baik. Oleh karena itu, diperlukan suatu perencanaan struktur yang tepat dan teliti agar dapat memenuhi kriteria kekuatan (strength), kenyamanan (serviceability), keselamatan (safety), dan umur rencana bangunan (durability) (Hardjoe, 2014).

Kerusakan pada bangunan struktur disebabkan oleh beberapa hal seperti, kesalahan dalam perhitungan atau perencanaan awal, kesalahan manusia (human error) pada saat pelaksanaan, faktor biaya, dan bencana alam. Bentuk dan tingkat kerusakan yang terjadi mulai dari ringan sampai berat. Jika kerusakan struktur bangunan telah terjadi, maka kekuatan (strength), kenyamanan (serviceability), keselamatan (safety), dan umur rencana bangunan (durability) yang telah direncanakan tidak mungkin terlaksana dengan baik. Perbaikan atau perkuatan harus dilakukan jika kerusakan struktur terjadi agar tujuan dari pembangunan tersebut dapat dicapai kembali.

Pelat merupakan komponen struktur yang pertama kali menerima beban mati maupun beban hidup. Beban dari pelat tersebut didistribusikan ke balok, lalu dari balok didistribusikan ke kolom. Jika pada pelat terjadi kerusakan maka pendistribusian beban tidak terjadi dengan baik dan fungsi dari bangunan itu tidak terlaksana sebagaimana mestinya. Pelat merupakan salah satu komponen struktur bangunan yang penting dan harus diperhatikan.

Jika material pelat lantai adalah beton bertulang, maka kerusakan yang terjadi dapat berupa retak (cracks) atau pecah pada beton dalam garis-garis yang relatif panjang sempit, voids atau lubang-lubang relatif dalam dan lebar pada beton, ataupun scalling kelupasan dangkal pada permukaan (Isneini, M., 2013). Metode perbaikan dan perkuatan pelat lantai juga bermacam-macam tergantung tipe kerusakan yang terjadi. 
Perkuatan pelat yang dilakukan harus mempertimbangkan antara biaya, waktu, dan mutu perkuatan. Perkuatan pada pelat lantai mempunyai beberapa solusi, yaitu: menggunakan FRP, menambah tebal pelat, dan sebagainya. Memilih perkuatan pelat yang efektif memerlukan beberapa pertimbangan, antara lain: seberapa besar pengaruh dari perkuatan yang dilakukan, biaya perkuatan, waktu pekerjaan, dan metode pelaksanaan pekerjaan. Analisis yang dilakukan untuk mengetahui seberapa besar pengaruh dari perkuatan pelat, adalah dengan metode itu adalah Metode Elemen Hingga (MEH). Metode tersebut diaplikasikan mulai dari analisis stress (tegangan), dan deformasi pada bidang struktur bangunan. Saat ini, banyak software yang dapat digunakan untuk menganalisis MEH, salah satunya Autodesk Nastran In-Cad 2016.

Melakukan analisis pelat menggunakan software Autodesk Nastran In-Cad 2016, membutuhkan data yang lengkap, yaitu: dimensi pelat, tebal pelat, mutu beton, diameter tulangan, jenis tulangan, dan spasi antar tulangan. Oleh sebab itu, dibutuhkan investigasi dan uji lapangan. Investigasi dilakukan untuk mengetahui tebal pelat, dimensi pelat, sedangkan pengujian lapangan dilakukan untuk mengetahui mutu beton, diameter tulangan, jenis tulangan, dan spasi antar tulangan. Uji lapangan yang dilakukan berupa pemeriksaan konfigurasi tulangan beton, dan uji kuat tekan beton inti. Penelitian bertujuan menganalisis struktur pelat eksisting, dan perkuatannya dengan metode $\mathrm{MEH}$ dengan menggunakan software Autodesk Nastran In-Cad 2016 dan menganalisis struktur pelat berdasarkan metode pelaksanaan pekerjaan, analisis biaya perkuatan pelat, dan lamanya waktu pengerjaan untuk mendapatkan jenis perkuatan yang efektif.

\section{TINJAUAN LITERATUR}

\section{Struktur Beton Bertulang}

Beton bertulang merupakan gabungan material beton dan baja tulangan, hal ini dilakukan untuk mengatasi kelemahan material beton dalam menahan tarik (Imran, S., dkk., 2014). Menurut SNI 2847-2013, beton adalah campuran semen portland atau semen hidrolis lainnya, agregat halus, agregat kasar, dan air, dengan atau tanpa bahan campuran tambahan (admixture). Beton bertulang adalah beton struktural yang ditulangi dengan tidak kurang dari jumlah baja prategang atau tulangan non-prategang minimum.

Beton terbuat dari bahan yang bersifat linear elastik, tetapi hubungan teganganregangannya cenderung bersifat non-linear, bahkan pada saat menahan beban yang kecil sekalipun. Karakteristik non-linear dapat ditimbulkan oleh beberapa faktor seperti riwayat pembebanan, efek jangka panjang, perilaku plastisitas akibat friksi internall, dan lain-lain

Perbandingan Analisis Perkuatan Struktur Pelat Dengan Metode Elemen Hingga 
(Imran, S. dkk., 2014). Kurva hubungan antara tegangan dan regangan beton menurut Hognestad dapat dilihat pada Gambar 2.1.

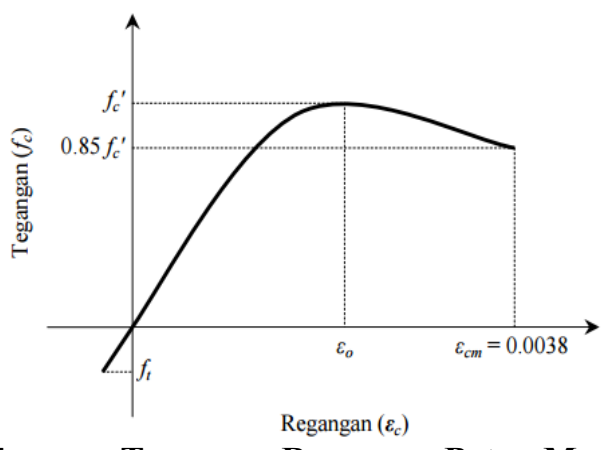

Gambar 2.1 Hubungan Tegangan Regangan Beton Menurut Hognestad

Sumber: Nur, 2009

Formulasi yang digunakan oleh Hognestad untuk mengambarkan tegangan tekan beton sebagai fungsi regangan tekan beton adalah:

1. Untuk daerah $\varepsilon_{\mathrm{c}} \leq \varepsilon_{0}$, tegangan tekan beton pada tegangan $\varepsilon_{\mathrm{c}}$ dihitung menggunakan Persamaan 2.1.

$$
\mathrm{f}_{\mathrm{c}}=\mathrm{f}_{\mathrm{c}},\left[\frac{\mathbf{m}}{\mathbf{m}}-\left[\frac{\mathbf{m}}{\mathbf{m}}\right]^{2}\right] \mathrm{MPa} ; \varepsilon_{0}=\frac{\mathbf{M} \boldsymbol{v}}{\mathbf{m}}
$$

2. Untuk daerah $\varepsilon_{0} \leq \varepsilon_{\mathrm{c}} \leq \varepsilon_{\mathrm{cm}}$, tegangan tekan beton pada tegangan $\varepsilon_{\mathrm{c}}$ dihitung menggunakan Persamaan 2.2.

$$
\mathrm{f}_{\mathrm{c}}=\mathrm{f}_{\mathrm{c}}{ }^{\prime}\left[1-100\left(\varepsilon_{\mathrm{c}}-\varepsilon_{0}\right)\right] \mathrm{MPa}
$$

\section{Keterangan:}

$\varepsilon_{\mathrm{c}}=$ regangan tekan beton

$\varepsilon_{0}=$ regangan tekan beton pada tegangan $\mathrm{f}_{\mathrm{c}}{ }^{\prime}$

$\varepsilon_{\mathrm{cm}}=$ regangan tekan beton maksimum

$\mathrm{f}_{\mathrm{c}}=$ tegangan tekan beton pada regangan $\varepsilon_{\mathrm{c}}$

$\mathrm{f}_{\mathrm{c}}{ }^{\prime}=$ kuat tekan uniaksial beton

Tegangan pada benda didefinisikan sebagai gaya persatuan luas penampang benda tersebut. Benda dengan penampang kecil diberi gaya akan mengalami tegangan yang lebih besar dibandingkan benda dengan penampang besar. Perhitungan tegangan dapat dilihat pada Persamaan 2.3.

$\sigma=\mathrm{F} / \mathrm{A}$

Keterangan:

$\mathrm{F}=$ Besar gaya tekan $(\mathrm{N})$

$\mathrm{A}=$ Luas penampang $\left(\mathrm{mm}^{2}\right)$ 
$\sigma=$ Tegangan $\left(\mathrm{N} / \mathrm{mm}^{2}\right)$

\section{Struktur Baja}

Baja merupakan material dengan besi sebagai material utamanya. Struktur baja sering digunakan dalam pembangunan, karena memiliki beberapa keunggulan yaitu: mempunyai kekuatan yang tinggi, keseragaman dan keawetan tinggi, memiliki sifat elastis, daktilitas pada baja cukup tinggi, memiliki kemudahan pada saat penyambungan antar elemen yang satu dengan lainnya. Selain itu, baja memiliki beberapa kekurangan seperti pada sisi pemeliharaan, selain itu baja juga dapat mengalami penurunan kekuatan yang besar akibat kenaikan temperatur yang cukup tinggi karena baja merupakan konduktor panas yang baik. Sifat mekanis baja dapat dilihat pada Tabel 2.1.

Tabel 2.1 Sifat Mekanis Baja Struktural

\begin{tabular}{cccc}
\hline $\begin{array}{c}\text { Jenis } \\
\text { Baja }\end{array}$ & $\begin{array}{c}\text { Tegangan putus } \\
\text { Minimum } f_{u} \\
(\mathrm{MPa})\end{array}$ & $\begin{array}{c}\text { Tegangan Leleh } \\
\text { Minimum } f_{y} \\
(\mathrm{MPa})\end{array}$ & $\begin{array}{c}\text { Peregangan } \\
\text { Minimum (\%) }\end{array}$ \\
\hline BJ 34 & 340 & 210 & 22 \\
BJ 37 & 370 & 240 & 20 \\
BJ 41 & 410 & 250 & 18 \\
BJ 50 & 500 & 290 & 16 \\
BJ 55 & 550 & 410 & 13 \\
\hline
\end{tabular}

Sumber: Setiawan, 2013

\section{Metode Elemen Hingga (MEH)}

Elemen adalah susunan materi yang mempunyai bentuk relatif teratur, dan mempunyai sifat-sifat tertentu yang tergantung pada bentuk fisik, dan materi penyusunnya serta menggambarkan totalitas dari elemen tersebut (Bangun, M., 2011). Metode elemen hingga adalah suatu metode pemaparan bagaimana perjalanan aksi hingga timbul reaksi dalam materi, atau metode untuk memperkirakan besar reaksi dan reaksi yang timbul dari materi tersebut. Kontinum dibagi menjadi beberapa bagian yang lebih kecil, maka elemen kecil ini disebut elemen hingga. Proses pembagian kontinum menjadi elemen hingga disebut proses diskretisasi atau pembagian. Metode elemen hingga dapat mengubah suatu masalah dengan jumlah derajat kebebasan tertentu sehingga proses pemecahannya akan lebih sederhana. Misalnya suatu batang panjang yang bentuk fisiknya tidak beraturan, dipotong-potong sependek mungkin sehingga terbentuk batangbatang pendek yang relatif lurus. Bentang panjang disebut kontinum, dan bentang pendek 
disebut elemen hingga. Elemen hingga adalah elemen diskrit dari suatu kontinum yang perilaku strukturnya dapat mewakili perilaku struktur kontinum secara keseluruhan (Siburian, S., 2010).

Konsep dasar metode elemen hingga yaitu suatu sistem mendapat gaya luar, kemudian diserap oleh sistem tersebut sehingga menimbulkan gaya dalam dan perpindahan. Mengetahui besarnya gaya dalam dan perpindahan akibat gaya luar, perlu dibentuk suatu persamaan yang mewakili sistem tersebut. Dalam metode elemen hingga keseluruhan sistem dibagi ke dalam elemen elemen dengan jumlah tertentu, yang selanjutnya dibentuk persamaan seperti pada Persamaan 2.4.

$$
[\mathrm{K}]\{\mathrm{D}\}=\{\mathrm{R}\}
$$

Keterangan:

$[\mathrm{K}] \quad=$ matriks kekakuan global

$\{\mathrm{D}\} \quad=$ matriks perpindahan global

$\{\mathrm{R}\} \quad=$ matriks gaya global

Proses pembentukan Persamaan 2.4 harus memenuhi kondisi berikut:

1. Kesetimbangan, yaitu kesetimbangan gaya gaya yang bekerja pada setiap elemen dan keseluruhan material;

2. Berkaitan dengan geometri dari material yaitu hubungan perpindahan dengan dan regangan;

3. Persamaan konstitutif dari material, mengenai hubungan tegangan regangan yang merupakan karakteristik dari material.

\subsection{Jenis Perkuatan Struktur Pelat}

Pada umumnya kerusakan pelat yang terjadi tergantung dari material yang digunakan. Jika material pelat lantai adalah beton bertulang maka kerusakan yang terjadi dapat berupa retak (cracks) atau pecah pada beton dalam garis-garis yang relatif panjang sempit, voids atau lubang-lubang relatif dalam dan lebar pada beton, ataupun scalling kelupasan dangkal pada permukaan (Rezady, D., dkk., 2003). Jenis perkuatan pelat lantai akibat gaya lentur atau beban yang dipikul dapat bermacam-macam, di antaranya:

1. Fiber Reinforced Polymer (FRP).

Fiber reinforced polymer adalah suatu material komposit yang digunakan dalam konstruksi sipil sebagai bahan perkuatan struktur. Bahan ini menggabungkan resin, filler, dan fiber. Resin yang digunakan adalah polyester, vinylester atau epoxy. Filler yang digunakan kaolin clay, calcium carbonat, dan alumina. FRP terdiri dari beberapa 
jenis, seperti glass, aramic, dan carbon. FRP merupakan bahan non korosif dan netral terhadap gaya magnet jika dibandingkan terhadap baja. FRP mempunyai kuat tarik lebih besar dari baja, modulus elastisitas kecil, dan hubungan tegangan-regangan adalah elastis. FRP merupakan material bangunan yang dibuat untuk memperkuat struktur bangunan dengan ruang seminimum mungkin sehingga tidak mempersempit ruangan ataupun merusak nilai arsitektural bangunan.

Kapasitas lentur pelat didasarkan pada kekuatan batas ultimit, yang ditentukan oleh batasan kuat tekan beton dan tegangan leleh baja tulangan serta tegangan efektif Fiber Reinforced Polymer (FRP). Hubungan diagram tegangan regangan perkuatan lentur dapat dilihat pada Gambar 2.2.

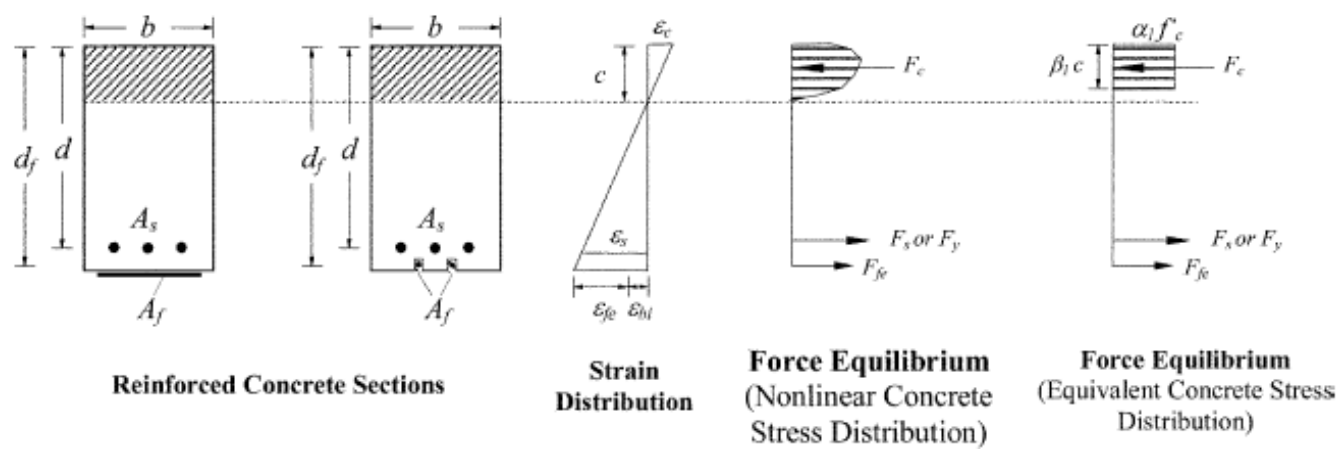

Gambar 2.2 Hubungan Diagram Tegangan Regangan Perkuatan Lentur

Sumber: ACI 440.2R-02, 2002

Luas penampang FRP dapat dihitung menggunakan Persamaan 2.5:

$A_{f}=n t_{f} . w_{f}$

Keterangan:

$N t_{f} \quad=$ jumlah lapis FRP yang digunakan

$t_{f} \quad=$ tebal FRP

$w_{f} \quad=$ lebar FRP

Tegangan efektif FRP dihitung berdasarkan Persamaan 2.6:

$f_{f u}=C_{e} \cdot f_{f u}^{*}$

Keterangan:

$f_{f u} \quad=$ Kuat tarik FRP

$C_{e} \quad=$ Kuat tarik ultimate

$f^{*}{ }_{f u} \quad=$ Faktor reduksi lingkungan

Reganan efektif FRP dihitung berdasarkan Persamaan 2.7:

$\varepsilon_{f u}=C_{e} \cdot \varepsilon_{f u}$

Perbandingan Analisis Perkuatan Struktur Pelat Dengan Metode Elemen Hingga 
Keterangan:

$\varepsilon_{f u} \quad=$ Regangan FRP

$C_{e} \quad=$ Kuat tarik ultimate

$\mathcal{E}^{*} f u=$ Regangan pecah

2. Penambahan balok.

Tujuan perkuatan ini adalah memperkecil gaya-gaya dalam yang terjadi. Umumnya dilakukan dengan menambah balok dari material baja (IWF). Konstruksi baja lebih mudah dan lebih praktis dibandingkan dengan konstruksi beton dalam melakukan perkuatan pelat, karena tidak perlu dilakukan pengecoran dan waktu pekerjaan jauh lebih cepat. Sambungan antara balok baja dengan pelat lantai ataupun balok eksisting menggunakan perekat yang disebut epoxy, lalu dilakukan pengangkuran.

\section{Autodesk Nastran In-Cad 2016.}

Autodesk Nastran In-Cad 2016 adalah solusi finite element analysis (FEA) untuk menganalisis tekanan linear dan nonlinear, dinamika, dan karakter perpindahan panas dari struktur dan komponen mekanikal, serta menyediakan hasil nyata dan perubahan pada parameter solusi ketika sedang proses penyelesaian. Autodesk Nastran In-Cad 2016 melakukan analisis untuk mendapatkan hasil akurat pada simulasi kompleks. Software ini merupakan sebuah perangkat FEA multi fungsi, sudah termasuk CAD (CAD-embedded) yang didukung oleh Autodesk Nastran Solver (Tarigan, I.A., 2016). Nastran In-CAD 2016 juga menyediakan simulasi pada berbagai tipe analisis, dan simulasi pada alur kerja CAD-embedded.

\section{METODE PENELITIAN}

\section{Diagram Alir Penelitian}

Diagram alir menunjukkan langkah-langkah pengerjaan secara keseluruhan dari penelitian ini. Dalam penelitian dilakukan pengumpulan data struktur pelat yang akan ditinjau dengan memilih data struktur pelat salah satu bangunan di Kota Jakarta. Pengumpul data bangunan tersebut mulai dari data struktur, data gambar, hasil uji lapangan, beserta lampiran yang ada. Selanjutnya dilakukan pengolahan data sekunder dan investigasi untuk mendapatkan data struktur pelat lantai yang ditinjau. Setelah mendapat data struktur pelat maka dilakukan pemodelan pelat lantai. Analisis pelat lantai akibat beban dilakukan dengan bantuan program Autodesk Nastran In-Cad 2016. Lalu 
dilakukan pemodelan pelat lantai dengan dua jenis perkuatan. Pertama, perkuatan pelat lantai dilakukan dengan menggunakan FRP.

Kedua, perkuatan pelat lantai dilakukan dengan memperpendek bentang pelat lantai dengan menambah balok IWF. Analisis perkuatan menggunakan FRP dan menambah balok IWF dilakukan dengan bantuan program Autodesk Nastran In-Cad 2016. Setelah dilakukan analisis, untuk membandingkan perkuatan pelat lantai yang efektif dan efisien maka perlu dilakukan analisis biaya dan metode pelaksanaan dengan dua jenis perkuatan pelat lantai tersebut. Sebelum dilakukan analisis terhadap biaya dan metode pelaksanaan, dilakukan wawancara kepada narasumber untuk mengetahui perkiraan biaya perkuatan menggunakan FRP dan menambah balok IWF.

Setelah mempertimbangkan perkuatan pelat lantai berdasarkan hasil analisis, biaya, dan metode pelaksaaan selanjutnya, dilakukan evaluasi jenis perkuatan mana yang paling efektif, menggunakan FRP atau menambah balok IWF. Diagram alir dari penelitian dapat dilihat pada Gambar 3.1. 


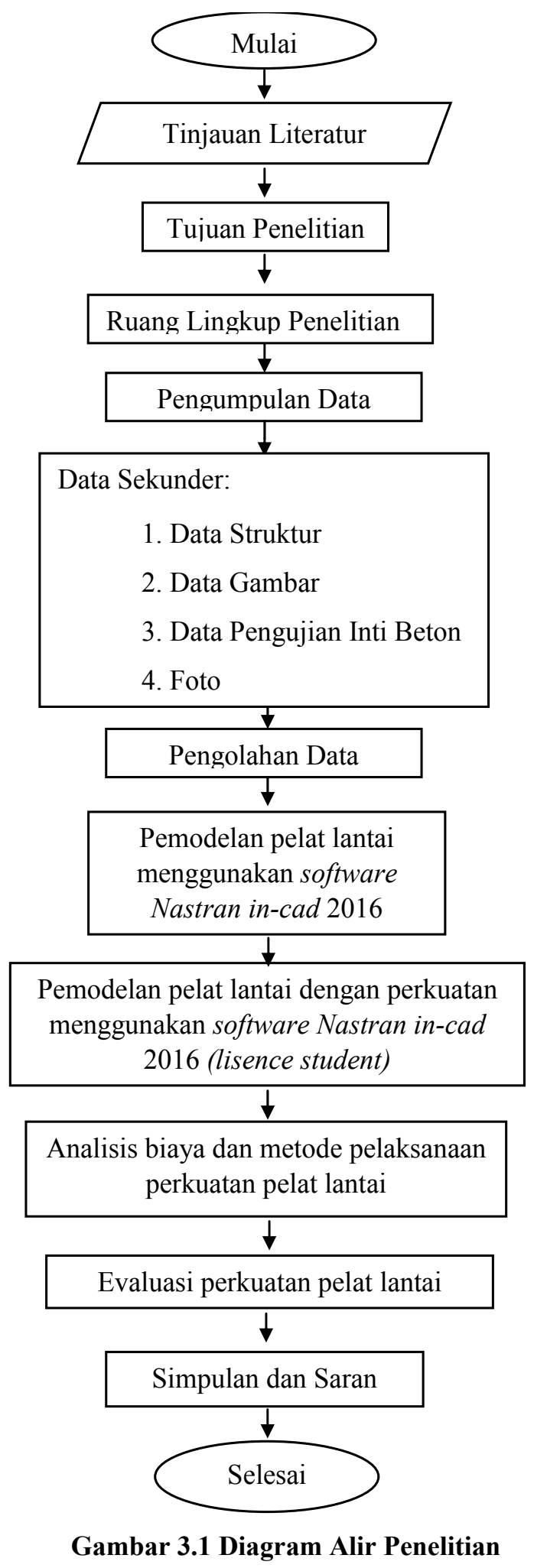




\section{Investigasi dan Pengolahan Data Sekunder}

Investigasi bangunan eksisting dilakukan pada gedung $\mathrm{X}$ yang berlokasi di Kota Jakarta pada tanggal 19 Oktober 2016 dengan mendapat surat resmi pengantar dan permintaan izin pada Badan Rumah Tangga Pengelola Gedung X. Pelat lantai yang ditinjau adalah pelat Lt.4 (1'2-BB') seperti pada Gambar 3.2. Hasil investigasi didapatkan foto yang dapat dilihat pada Tabel 3.1.

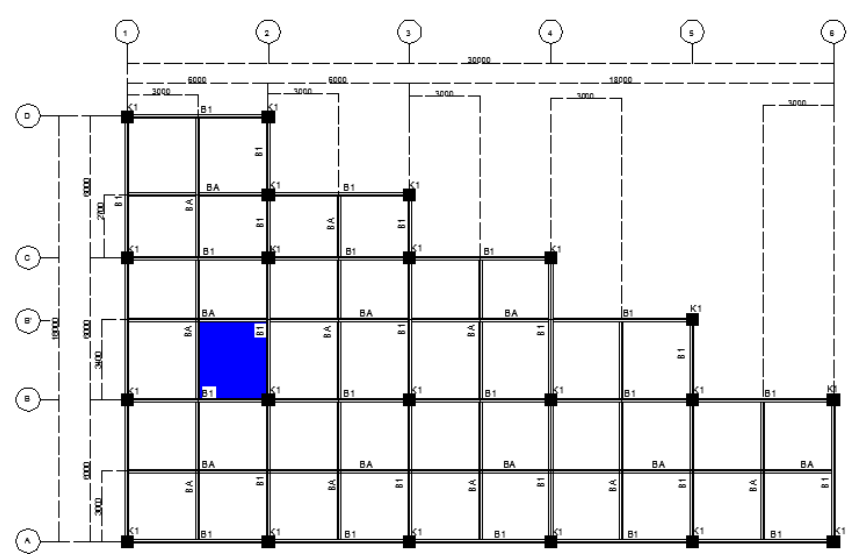

Gambar 3.2 Lokasi Pelat Lt.4 (1'2-BB')

Tabel 3.1 Foto Investigasi Lt.4 Gedung $X$

\begin{tabular}{|l|l|}
\hline Foto & Keterangan \\
\hline & Ruang Arsip Lt.4 \\
\hline & Kondisi Pelat Lt. 4 (1'2-BB') \\
\hline & \\
\hline
\end{tabular}

Perbandingan Analisis Perkuatan Struktur Pelat Dengan Metode Elemen Hingga 
Pelat Lt.4 (1'2-BB') dengan bentang 3400x3000 mm memiliki mutu pelat sebesar 18,04MPa. Tebal pelat lantai adalah $108 \mathrm{~mm}$. Diameter tulangan yang digunakan $8 \mathrm{~mm}$ dengan spasi antar tulangan $10 \mathrm{~mm}$ untuk arah $\mathrm{x}$ dan $\mathrm{y}$. Selimut beton adalah $25 \mathrm{~mm}$. $F c^{\prime}$

$$
=18,04 \mathrm{MPa}
$$

1. $E_{\text {beton }}$

2. Ybeton

3. Tebal pelat

4. Selimut Beton

5. Diameter tulangan

6. $F y$

7. $E_{\text {baja }}$

8. Jarak antar tulangan

Arah-x

Arah-y

$$
=4700 \sqrt{\boldsymbol{r}}=19962,6 \mathrm{MPa}
$$$$
=2400 \mathrm{~kg} / \mathrm{m}^{3}
$$$$
=108 \mathrm{~mm}
$$

$=25 \mathrm{~mm}$

$=\varnothing 8 \mathrm{~mm}$

$=240 \mathrm{MPa}$

$$
=200000 \mathrm{MPa}
$$

$=10 \mathrm{~cm}$

$=10 \mathrm{~cm}$

Detail pelat Lt.4 (1'2-BB') berdasarkan data struktur yang ada dapat dilihat pada Tabel

\begin{tabular}{|c|c|c|}
\hline Tampak Atas & Potongan & \\
\hline & $3000 \mathrm{~mm}$ & $-\frac{28.100}{7}$ \\
\hline & POTONGAN - $\mathrm{X}$ & $100 \mathrm{~mm} \quad \square 8-100$ \\
\hline & $3400 \mathrm{~mm}$ & $08-100$ \\
\hline & POTONGAN - Y & $100 \mathrm{~mm} \quad 88-100$ \\
\hline oevirenter & & \\
\hline
\end{tabular}
3.3 .

Tabel 3.3 Detail Pelat Lt.4 (1'2-BB')

\section{Pemodelan Struktur Pelat Menggunakan Software Autodesk Nastran In-Cad 2016}

Pemodelan struktur pelat menggunakan bantuan dari software Autodesk Inventor Professional 2016. Melakukan analisis pada Autodesk Nastran In-Cad 2016, harus menggunakan Autodesk Inventor Professional 2016, karena Nastran In-Cad 2016 merupakan salah satu bagian dalam Autodesk Inventor Professional 2016. Pelat harus digambar atau didesain terlebih dahulu sebelum analisis dilakukan. Hal itu dilakukan pada software Autodesk Inventor Professional 2016. 
Jika Pelat lantai telah sesuai dengan desain, dengan lebar 3000mm, panjang $3400 \mathrm{~mm}$, tebal pelat $108 \mathrm{~mm}$, selimut beton $20 \mathrm{~mm}$ dengan tulangan dua arah yang memiliki spasi antar tulangan $100 \mathrm{~mm}$, langkah selanjutnya adalah melakukan analisis pada program Autodesk Nastran In-Cad, dengan cara pilih environment > Autodesk Nastran In-Cad, lalu masukan spesifikasi material pelat dan beban yang akan dipikul oleh pelat, jika pemodelan pelat telah selesai seperti pada Gambar 3.4, maka analisis dapat dilakukan.

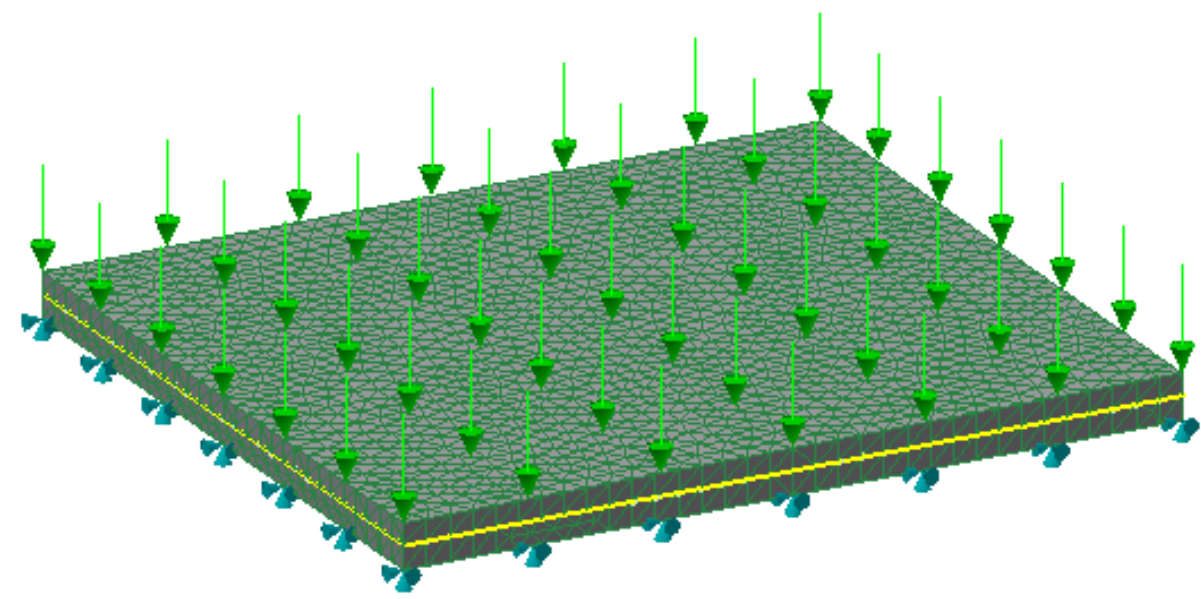

Gambar 3.4 Pemodelan Pelat

Perkuatan Struktur Pelat Lantai.

Perkuatan struktur pelat yang dilakukan adalah membandingkan antara perkuatan menggunakan FRP dan menggunakan balok IWF.

\section{Perkuatan Pelat dengan Menggunakan FRP Model Satu.}

Perkuatan pelat dengan menggunakan FRP model satu adalah perkuatan pelat dengan menggunakan FRP pada seluruh permukaan bawah pelat lantai. Perkuatan dengan FRP ini memang memiliki biaya yang sangat mahal. Perkuatan dengan FRP pada seluruh permukaan bawah pelat digunakan jika pelat lantai telah mengalami kerusakan berat akibat beban yang ada. FRP yang digunakan adalah FRP jenis SikaWrap Hex 103C (Carbon Fiber Fabric (dry lay-up)) dengan data FRP:

$$
\begin{aligned}
& \text { tebal }=0,33 \mathrm{~mm} \quad \text { tensile strength }=960 \mathrm{MPa} \\
& \text { elongation }=1,33 \% \quad \text { tensile modulus }=73.100 \mathrm{MPa} \\
& \mathrm{C}_{\mathrm{E}} \quad=0,95 \quad \text { modulus elastis } \quad=230000 \mathrm{MPa} \\
& \begin{array}{llll}
\mathrm{Xmf}_{\mathrm{mf}} & =1,4 & \mathrm{\gamma}_{\mathrm{mm}} & =1.4
\end{array} \\
& \mathrm{X}_{\mathrm{mE}}=1,1
\end{aligned}
$$

Perbandingan Analisis Perkuatan Struktur Pelat Dengan Metode Elemen Hingga 
Detail perkuatan dengan FRP model satu dapat dilihat pada Tabel 3.4.

Tabel 3.4 Detail Pelat dengan Perkuatan FRP Model Satu

\begin{tabular}{|c|c|c|c|}
\hline No. & \multicolumn{3}{|c|}{ Gambar } \\
\hline \multirow[t]{2}{*}{1.} & \multirow{2}{*}{\multicolumn{3}{|c|}{ arah serat FRP $=$ arah y }} \\
\hline & & & \\
\hline \multirow[t]{2}{*}{2.} & \multicolumn{2}{|r|}{$3000 \mathrm{~mm}$} & $08-100$ \\
\hline & FRP & POTONGAN - X & $100 \mathrm{~mm}$ \\
\hline \multirow[t]{2}{*}{3.} & 番-100 & $3400 \mathrm{~mm}$ & \\
\hline & FRP & POTONGAN - Y & $100 \mathrm{~mm}$ \\
\hline
\end{tabular}

\section{Perkuatan Pelat dengan Menggunakan FRP Model Dua}

Perkuatan pelat dengan menggunakan FRP model dua adalah perkuatan pelat dengan menggunakan FRP pada permukaan bawah pelat lantai dengan posisi seperti pada Tabel 3.6. Perkuatan dengan FRP ini memang memiliki biaya yang mahal, tetapi biaya FRP model dua di bawah dari perkuatan dengan FRP model satu karena FRP tidak dipasang pada semua permukaan. FRP yang digunakan adalah FRP jenis SikaWrap Hex 103C (Carbon Fiber Fabric (dry lay-up)) dengan data FRP:

\begin{tabular}{|c|c|c|c|}
\hline tebal & $=0,33 \mathrm{~mm}$ & tensile strength & $=960 \mathrm{MPa}$ \\
\hline elongation & $=1,33 \%$ & tensile modulus & $=73.100 \mathrm{MPa}$ \\
\hline $\mathrm{C}_{\mathrm{E}}$ & $=0,95$ & modulus elastis & $=230000 \mathrm{MPa}$ \\
\hline $\mathrm{Ymf}$ & $=1,4$ & $\mathrm{Y}_{\mathrm{mm}}$ & $=1.4$ \\
\hline$\gamma_{\mathrm{mE}}$ & $=1,1$ & lebar FRP & $=250 \mathrm{~mm}$ \\
\hline
\end{tabular}

Detail perkuatan dengan FRP model dua dapat dilihat pada Tabel 3.5 
Tabel 3.5 Detail Pelat dengan Perkuatan FRP Model Dua

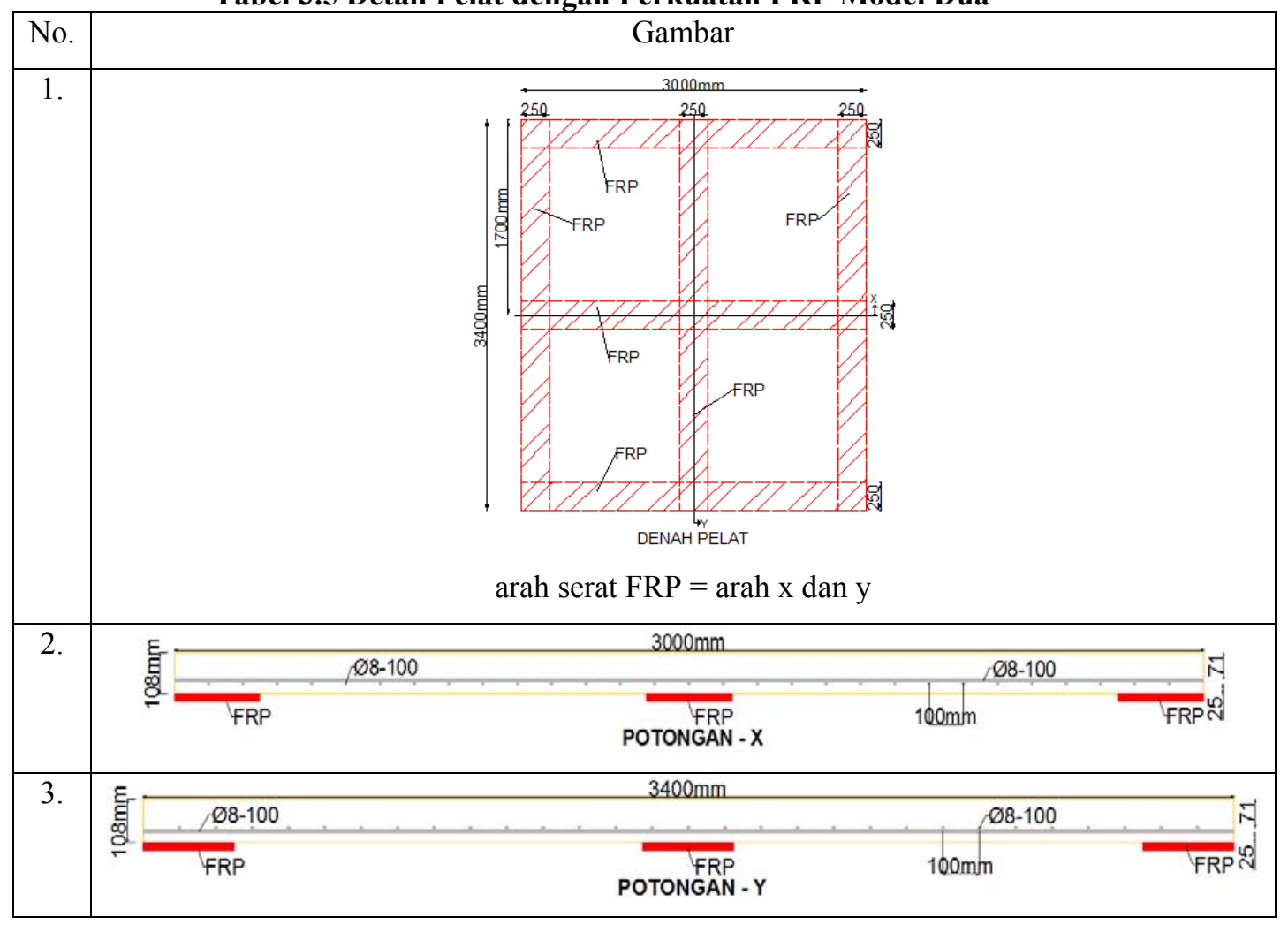

\section{Perkuatan Pelat dengan Menggunakan FRP Model Tiga.}

Perkuatan pelat dengan menggunakan FRP model tiga adalah perkuatan pelat dengan menggunakan satu lapis FRP pada tengah bentang pelat lantai dengan posisi seperti pada Tabel 3.7. Perkuatan dengan FRP ini memang memiliki biaya cukup mahal dibanding menggunakan IWF, tetapi biaya FRP model tiga di bawah dari perkuatan dengan FRP model satu dan dua karena FRP hanya dipasang satu buah. FRP yang digunakan adalah FRP jenis SikaWrap Hex 103C (Carbon Fiber Fabric (dry lay-up)) dengan data FRP:

\begin{tabular}{|c|c|c|c|}
\hline tebal & $=0,33 \mathrm{~mm}$ & tensile strength & $=960 \mathrm{MPa}$ \\
\hline elongation & $=1,33 \%$ & tensile modulus & $=73.100 \mathrm{MPa}$ \\
\hline $\mathrm{C}_{\mathrm{E}}$ & $=0,95$ & modulus elastis & $=230000 \mathrm{MPa}$ \\
\hline $\mathrm{Ymf}$ & $=1,4$ & $\mathrm{Y}_{\mathrm{mm}}$ & $=1.4$ \\
\hline$\gamma_{\mathrm{mE}}$ & $=1,1$ & lebar FRP & $=250 \mathrm{~mm}$ \\
\hline
\end{tabular}

Detail perkuatan dengan FRP model tiga dapat dilihat pada Tabel 3.6.

Tabel 3.6 Detail Pelat dengan Perkuatan FRP Model Tiga

Perbandingan Analisis Perkuatan Struktur Pelat Dengan Metode Elemen Hingga 


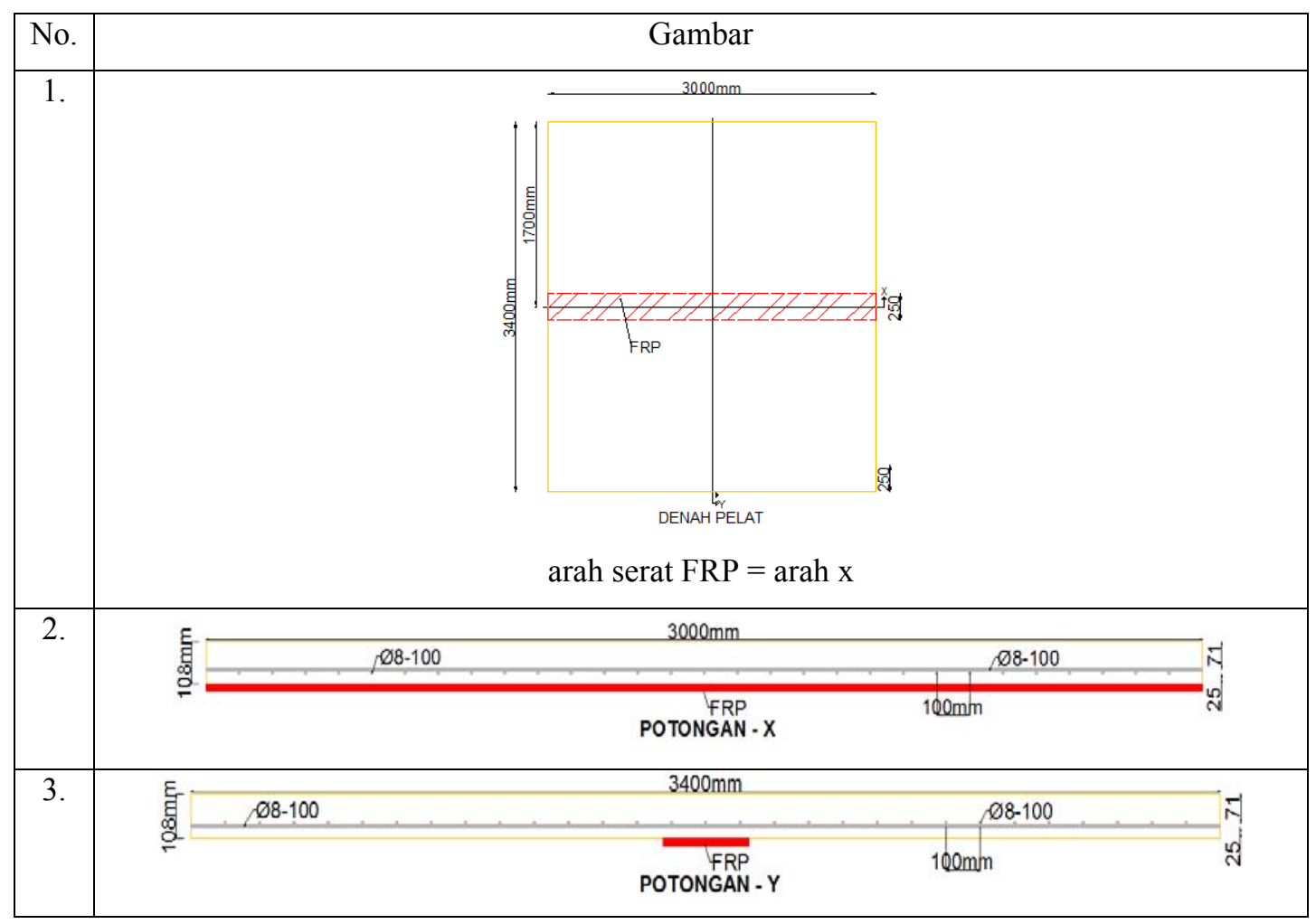

\section{Perkuatan Pelat dengan Menggunakan Balok IWF.}

Perkuatan pelat dengan menggunakan balok IWF pada tengah bentang untuk mengurangi atau membantu pelat menahan beban. Perkuatan dengan menggunakan balok IWF berfungsi memperpendek bentang pelat lantai sehingga beban yang dipikul oleh pelat lantai dapat disalurkan ke balok IWF. Letak balok IWF dipasang pada bentang 3400mm karena bentang tersebut merupakan bentang terpanjang pada pelat Lt.4 (1'2BB'). Detail perkuatan dengan balok IWF dapat dilihat pada Tabel 3.7. Balok IWF yang digunakan adalah IWF 150.100.6.9.11 dengan data profil sebagai berikut

Data profil IWF:
A $\quad=150 \mathrm{~mm}$
B $\quad=100 \mathrm{~mm}$
tw $\quad=6 \mathrm{~mm}$
tf $\quad=9 \mathrm{~mm}$
$\mathrm{r} \quad=11 \mathrm{~mm}$
A $\quad=26,84 \mathrm{~cm}^{2}$
$A g \quad=21,1 \mathrm{~kg} / \mathrm{m}$

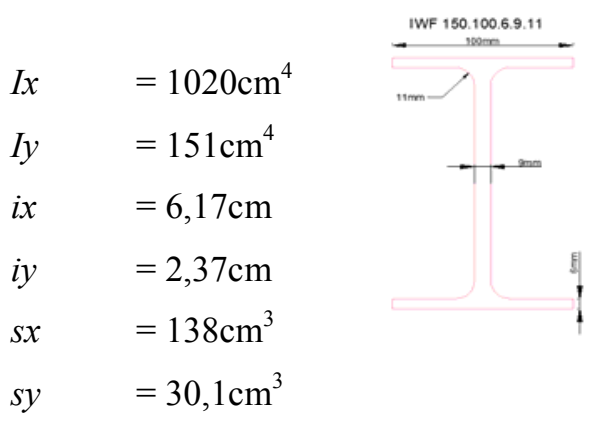


Tabel 3.7 Detail Pelat dengan Perkuatan Balok IWF

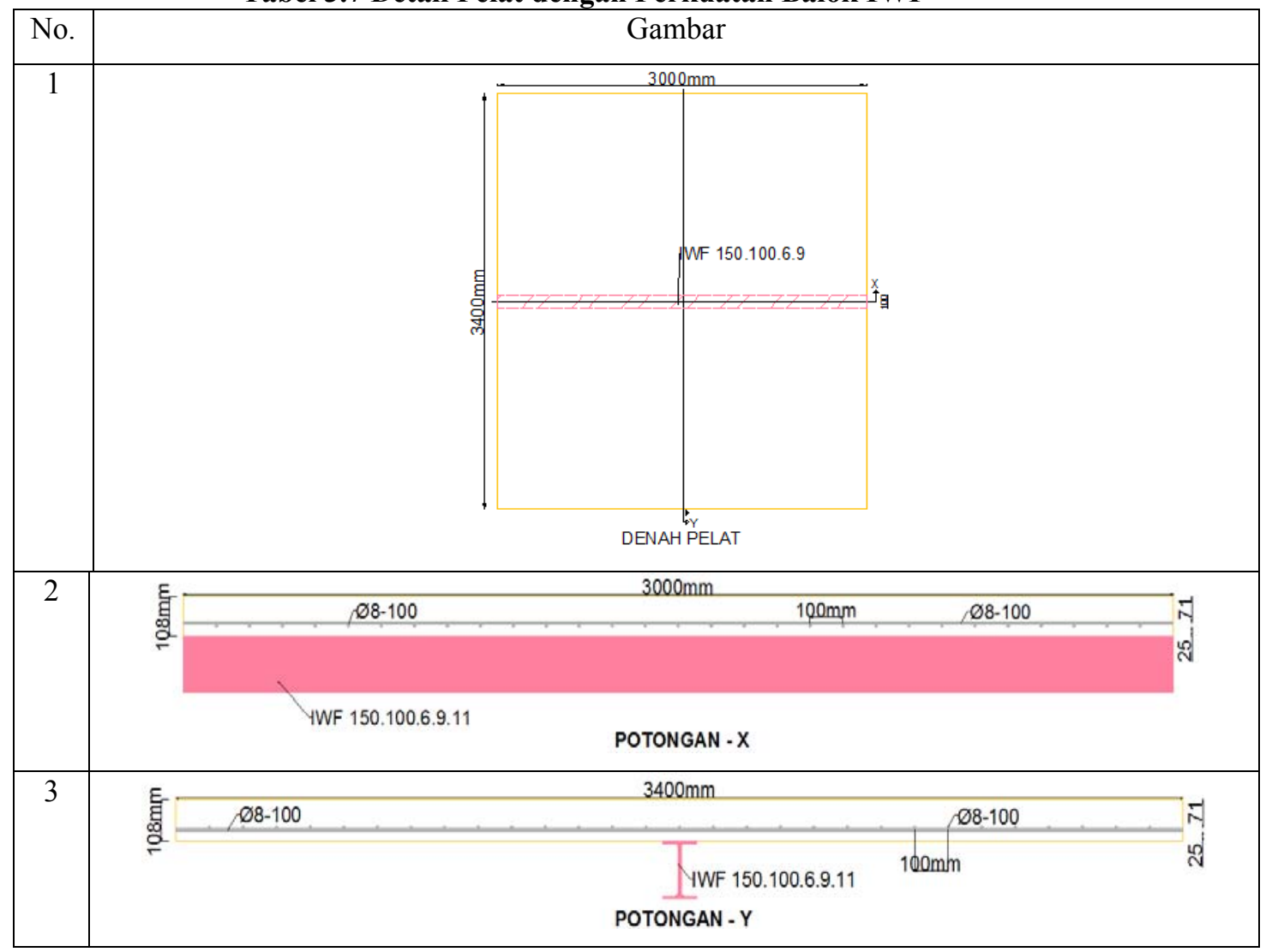

\section{Wawancara Estimasi Biaya dan Metode Pelaksanaan}

Tujuan wawancara adalah untuk mengetahui biaya dan metode pelaksanaan dari perkuatan yang akan dilakukan. Narasumber yang menjadi sample adalah distributor FRP beserta lem perekatnya dan kontraktor yang memiliki pengalaman cukup banyak dalam pembangunan. Selain itu wawancara juga dilakukan kepada pemilik toko bangunan yang berada di Kota Bandung. Narasumber dipilih karena memiliki pengalaman dalam bidangnya masing-masing dan bersedia untuk diwawancara. Hasil wawancara dapat dilihat pada Tabel 3.8. 
Tabel 3.8 Hasil Wawancara

\begin{tabular}{|c|c|c|c|c|}
\hline & KETERANGAN & PT. SIKA INDONESIA & $\begin{array}{c}\text { PT. BANGUN BERKAT } \\
\text { SAUDARA } \\
\end{array}$ & PT. TUNGGAL JAYA \\
\hline \multirow{2}{*}{ Pelaksanaan } & Tanggal wawancara & 28-Nov-16 & 26-Nov-16 & 26-Nov-16 \\
\hline & Jenis wawancara & Via telephone & Wawancara langsung & Wawancara langsung \\
\hline \multirow{5}{*}{ FRP } & \multirow{2}{*}{ Harga } & $\begin{array}{l}\text { FRP = Rp. } 11.000 .000,-/ \mathrm{rol} \\
(1 \mathrm{rol}=25 \mathrm{~m}(\mathrm{l}=50 \mathrm{~cm}))\end{array}$ & - & - \\
\hline & & $\begin{array}{l}\text { Lem sika = Rp. } 2.450 .000,- \\
/ 5 \mathrm{~kg}\end{array}$ & - & - \\
\hline & Metode pelaksanaan & $\begin{array}{l}\text { Pengeleman menggunakan } \\
\text { FRP menggunakan lem sika } \\
\text { dengan ketebalan 2-3mm }\end{array}$ & - & - \\
\hline & Waktu pengerjaan & Kurang dari satu hari & Kurang dari satu hari & - \\
\hline & Jumlah pekerja & Dua pekerja, dua laden & Dua pekerja, dua laden & \\
\hline \multirow{11}{*}{ IWF } & \multirow{5}{*}{ Harga } & - & Baja $=$ Rp. $8.700,-/ \mathrm{kg}$ & Baja = Rp. $9.000,-/ \mathrm{kg}$ \\
\hline & & - & Pelat baja = Rp. $10.000,-/ \mathrm{kg}$ & Pelat baja $=$ Rp. $9.500,-/ \mathrm{kg}$ \\
\hline & & - & - & $\begin{array}{l}\text { Chemical } \text { angkur }=\mathrm{Rp} . \\
300.000,-/ \text { tube }\end{array}$ \\
\hline & & - & - & $\begin{array}{l}\text { Angkur d12= Rp. } 35.000,- \\
\text { / buah }\end{array}$ \\
\hline & & - & - & $\begin{array}{l}\text { Dynabolt M10 = Rp. } \\
15.000,-/ \text { buah }\end{array}$ \\
\hline & \multirow{3}{*}{ Metode pelaksanaan } & - & $\begin{array}{l}\text { Penyambungan IWF ke balok } \\
\text { eksisting memerlukan pelat baja, dan } \\
\text { angkur }\end{array}$ & - \\
\hline & & - & $\begin{array}{l}\text { Penyambungan IWF ke pelat lantai } \\
\text { menggunakan dynabolt M10 }\end{array}$ & - \\
\hline & & - & $\begin{array}{l}\text { Pengeleman IWF menggunakan } \\
\text { chemical angkur }\end{array}$ & - \\
\hline & Waktu pekerjaan & - & Dua hari & - \\
\hline & Jumlah pekerja & - & Dua pekerja, dua laden & - \\
\hline & Waktu pengerjaan & - & dua hari & - \\
\hline \multirow{2}{*}{ Pekerja } & Biaya pekerja & - & Rp. $110.000,-/$ hari & - \\
\hline & Biaya laden & - & Rp. 85.000,-/hari & - \\
\hline
\end{tabular}

Keterangan:

- $\quad$ tidak dilakukan wawancara

\section{ANALISIS STRUKTUR}

\section{Perbandingan Hasil Analisis Pelat dan Perkuatan Pelat}

Hasil output analisis nonlinear yang didapat adalah nilai maksimum lendutan atau displacement dan applied load yang bekerja pada pelat lantai. Berdasarkan displacement yang terjadi pada saat total applied load 62915,3N, memiliki perbedaan yang cukup tinggi antara FRP dengan balok IWF, namun perlu memerhatikan sifat daktilitas yang dimiliki FRP dan untuk membandingkan harus dilihat dari sisi lain juga, seperti biaya dan metode pelaksanaan perkuatan. Persentase perkuatan pelat lantai dengan FRP dan perkuatan dengan balok IWF dapat dilihat pada Tabel 4.1. Hubungan displacement dengan total applied load pada pelat lantai, pelat lantai + FRP, pelat lantai + IWF dapat dilihat pada Gambar 4.1. Perbandingan tegangan yang terjadi pada tulangan baja dapat dilihat pada Tabel 4.2, dan perbandingan tegangan yang terjadi pada perkuatan pelat lantai dapat dilihat pada Tabel 4.3. 
Tabel 4.1 Persentase Perkuatan Pelat

\begin{tabular}{|c|c|c|c|c|c|}
\hline Keterangan & Pelat lantai & $\begin{array}{c}\text { Pelat lantai dengan FRP } \\
\text { model } 1\end{array}$ & $\begin{array}{c}\text { Pelat lantai dengan FRP } \\
\text { model } 2\end{array}$ & $\begin{array}{l}\text { Pelat lantai dengan FRP } \\
\text { model } 3\end{array}$ & Pelat lantai dengan IWF \\
\hline Pressure (MPa) & 0,0122 & 0,0122 & 0,0122 & 0,0122 & 0,0122 \\
\hline Displacement (mm) & 1,0882 & 0,2067 & 0,5860 & 0,896 & 0,7808 \\
\hline Persentase Perkuatan (\%) & - & 81,0048 & 46,1481 & 17,6599 & 28,2459 \\
\hline Gambar & 年 & $\frac{\text { E }}{{ }_{E}}$ & Perkuatan FRP model2 & Perkuatan FRP model3 & 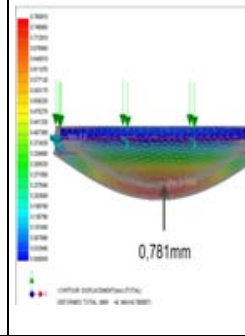 \\
\hline
\end{tabular}

Tabel 4.2 Perbandingan Tegangan Tulangan

\begin{tabular}{|c|c|c|c|c|c|}
\hline Keter mgan & Peht lantai & $\begin{array}{l}\text { Pelat hrtai dengen FRP } \\
\text { model } 1\end{array}$ & $\begin{array}{c}\text { Pe ht lontai dengh FRP } \\
\text { model } 2\end{array}$ & $\begin{array}{l}\text { Pe ht lontsi dengen FRP } \\
\text { model } 13\end{array}$ & Pe ht lontai dengn $\Gamma$ WF \\
\hline Msksimum (MPa) & $0 \rho 460$ & $0 \rho 250$ & 0,1820 & 0,3069 & 0,0370 \\
\hline Minimum (MPa) & $-1,5490$ & $-0,1490$ & -08630 & $-1,4767$ & -23180 \\
\hline Gambar & 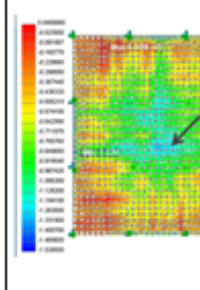 & Perkuatan FRP model1 & Perkuatan FRP model2 & Perkuatan FRP model3 & (1) \\
\hline
\end{tabular}

Tabel 4.3 Perbandingan Tegangan Perkuatan Pelat Lantai

\begin{tabular}{|c|c|c|c|c|c|}
\hline Keterangan & Pelat lartai & $\begin{array}{c}\text { Pelat lantai dengan FRP } \\
\text { model } 1\end{array}$ & $\begin{array}{c}\text { Pelat lantai dergan FRP } \\
\text { model } 2\end{array}$ & $\begin{array}{l}\text { Pelat lantai denganFRP } \\
\text { model } 3\end{array}$ & Pelat lantai dengen $W F$ \\
\hline Maksimum(MPa) & 40860 & 1,138 & 1,8560 & 3,896 & 3,4891 \\
\hline $\operatorname{Minimm}(\mathbf{M P a})$ & $-0,2740$ & $-0,1611$ & $-0,3052$ & $-0,2386$ & $-0,2194$ \\
\hline Ganbar & 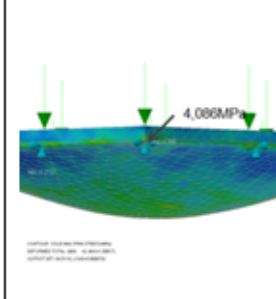 & Perkuatan FRP model1 & Perkuatan FRP mode12 & Perkuatan FRP model3 & 郒 \\
\hline
\end{tabular}




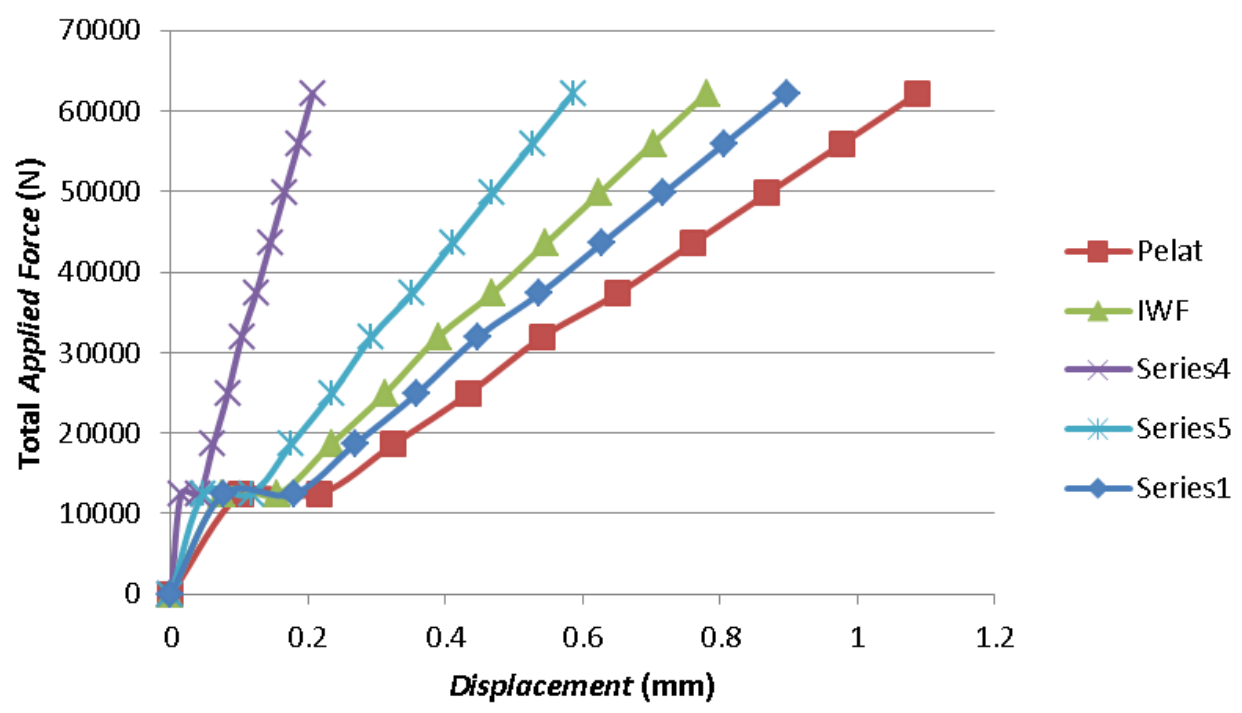

Gambar 4.1 Total Applied Load vs Displacement perbandingan antara pelat lantai, Pelat Lantai + FRP1, Pelat Lantai + FRP2, Pelat Lantai + FRP3, Pelat Lantai + IWF

\section{Perbandingan Biaya dan Waktu Pengerjaan Pelat}

Selain mempertimbangkan hasil analisis, untuk melakukan perkuatan harus dilihat dari biaya dan waktu pengerjaan. Hal tersebut agar mendapatkan perkuatan pelat yang paling efektif. Biaya, metode pekerjaan, dan perkiraan waktu menjadi pertimbangan penting untuk dilakukan perkuatan pelat lantai. Biaya perkuatan dengan FRP model satu adalah Rp.11.111.100,-, dengan FRP model dua adalah Rp. 5.452.700,-, dengan FRP model tiga adalah Rp.1.235.850,-, sedangkan biaya perkuatan menggunakan IWF adalah sebesar Rp. 1.449.432,-. Rincian biaya perkuatan pelat dapat dilihat pada Tabel 4.4 sampai dengan Tabel 4.7.

Tabel 4.4 Biaya Perkuatan Pelat Lantai dengan FRP Model Satu

\begin{tabular}{|l|l|l|l|lr|lr|}
\hline No. & Bahan dan Pekerja & Jumlah & Satuan & Harga Satuan (Rp) & Total Biaya & \\
\hline 1. & Pekerja & 2 & org & $\mathrm{Rp}$ & $110.000,00$ & $\mathrm{Rp}$ & $220.000,00$ \\
\hline 2. & Laden & 2 & org & $\mathrm{Rp}$ & $85.000,00$ & $\mathrm{Rp}$ & $170.000,00$ \\
\hline 3. & FRP & 10,2 & $\mathrm{~m} 2$ & $\mathrm{Rp}$ & $880.000,00$ & $\mathrm{Rp}$ & $8.976 .000,00$ \\
\hline 4. & Lem epoxy (sika) & 1,5 & $\mathrm{~kg}$ & $\mathrm{Rp}$ & $490.000,00$ & $\mathrm{Rp}$ & $735.000,00$ \\
\hline
\end{tabular}


Tabel 4.5 Biaya Perkuatan Pelat Lantai dengan FRP Model Dua

\begin{tabular}{|l|l|l|l|lr|rr|}
\hline No. & Bahan dan Pekerja & Jumlah & Satuan & Harga Satuan (Rq) & Total Biaya \\
\hline 1. & Pekerja & 2 & org & $\mathrm{Rp}$ & $110.000,00$ & $\mathrm{Rp}$ & $220.000,00$ \\
\hline 2. & Laden & 2 & org & $\mathrm{Rp}$ & $85.000,00$ & $\mathrm{Rp}$ & $170.000,00$ \\
\hline 3. & FRP & 4,8 & $\mathrm{~m} 2$ & $\mathrm{Rp}$ & $880.000,00$ & $\mathrm{Rp}$ & $4.224 .000,00$ \\
\hline 4. & Lem epoxy (sika) & 0,7 & $\mathrm{~kg}$ & $\mathrm{Rp}$ & $490.000,00$ & $\mathrm{Rp}$ & $343.000,00$ \\
\hline
\end{tabular}

Tabel 4.6 Biaya Perkuatan Pelat Lantai dengan FRP Model Tiga

\begin{tabular}{|c|c|c|c|c|c|c|}
\hline No. & Bahan dan Pekerja & Jumlah & Satuan & Harga Satuan (Rp) & Total Biaya & \\
\hline 1. & Pekerja & 2 & org & $\mathrm{R}_{\mathrm{p}} \quad 110.000,00$ & $\mathrm{Rp}_{\mathrm{p}}$ & $220.000,00$ \\
\hline 2. & Laden & 2 & org & $85.000,00$ & $\mathrm{Rp}$ & $170.000,00$ \\
\hline 3. & $F R P$ & 0,75 & $\mathrm{~m} 2$ & $880.000,00$ & $\mathrm{R}_{\mathrm{p}}$ & 660000,00 \\
\hline \multirow[t]{2}{*}{4.} & Lem epony (sika) & 0,15 & $\mathrm{~kg}$ & $490.000,00$ & $\mathrm{Rp}$ & $73.500,00$ \\
\hline & & & & Total & $\mathrm{Rp}_{\mathrm{p}}$ & $1.123 .500,00$ \\
\hline 5. & Keuntungan kontraktor & 10 & $\%$ & Total Peketjaatı & $\mathrm{Rp}$ & $112.350,00$ \\
\hline & & & & Biaya Total & $\mathbf{R}_{p}$ & $1.235 .850,00$ \\
\hline
\end{tabular}

Tabel 4.7 Biaya Perkuatan Pelat Lantai dengan IWF

\begin{tabular}{|c|c|c|c|c|c|c|c|}
\hline No. & Bahan dan Pekerja & Jumlah & Satuan & \multicolumn{2}{|c|}{ Harga Satuan (Rp) } & \multicolumn{2}{|c|}{ Total Biaya } \\
\hline 1. & Pekerja & 2 & org & $\mathrm{Rp}$ & $110.000,00$ & $\mathrm{Rp}$ & $440.000,00$ \\
\hline 2. & Laden & 2 & org & $\mathrm{Rp}$ & $85.000,00$ & $\mathrm{Rp}$ & $340.000,00$ \\
\hline 3. & Baja IWF & 63,3 & $\mathrm{~kg}$ & $\mathrm{Rp}$ & $9.000,00$ & $\mathrm{Rp}$ & $569.700,00$ \\
\hline 4. & Pelat Baja (t=10mm & 1,22 & $\mathrm{~kg}$ & $\mathrm{Rp}$ & $11.000,00$ & $\mathrm{Rp}$ & $13.420,00$ \\
\hline 5. & Chemical angkur & 1 & tube & $\mathrm{Rp}$ & $300.000,00$ & $\mathrm{Rp}$ & $300.000,00$ \\
\hline 6. & Angkur (d=12mtn) & 8 & buah & $\mathrm{Rp}$ & $35.000,00$ & $\mathrm{Rp}$ & $280.000,00$ \\
\hline \multirow[t]{2}{*}{7.} & Dynabolt MIO & 8 & buah & $\mathrm{Rp}$ & $15.000,00$ & \multirow{2}{*}{\multicolumn{2}{|c|}{$\begin{array}{ll}\text { Rp } & 120.000,00\end{array}$}} \\
\hline & & & & \multicolumn{2}{|c|}{ Total Pekerjaan } & $\begin{array}{ll}\operatorname{Rp} & 1.363 .120,00 \\
\end{array}$ & \\
\hline \multirow[t]{2}{*}{8.} & Keuntungan kontraktor & 10 & $\%$ & \multicolumn{2}{|c|}{ Total Pekerjaan } & & $136.312,00$ \\
\hline & & & & \multicolumn{2}{|c|}{ Biaya T otal } & \multicolumn{2}{|c|}{ Rp $1.499 .432,00$} \\
\hline
\end{tabular}

Metode pekerjaan dan lama pengerjaan merupakan hal yang menjadi pertimbangan dalam melakukan perkuatan pelat lantai, karena terkadang owner atau perencana memiliki biaya minim sehingga lebih memilih perkuatan pelat dengan biaya minim walaupun metode pelaksanaan cukup rumit dan membutuhkan waktu pengerjaan yang lebih lama. Tetapi, terkadang owner atau perencana ingin mempercepat waktu pengerjaan, sehingga memilih perkuatan pelat yang lebih mudah atau waktu pengerjaan yang lebih cepat walaupun dengan biaya perkuatan lebih besar. Metode pekerjaan dan waktu pengerjaan perkuatan pelat dengan FRP model satu, dua, dan tiga dapat dilihat pada Tabel 4.8. Metode pekerjaan dan waktu pengerjaan perkuatan pelat dengan IWF dapat dilihat pada Tabel 4.9. 
Tabel 4.8 Metode Pekerjaan dan Lama Waktu Pengerjaan Perkuatan Pelat Lantai dengan FRP Model Satu, Dua, dan Tiga

\begin{tabular}{|l|l|c|}
\hline No. & Langkah Kerja & Lama pengerjaan \\
\hline 1. & Pembersihan lahan kerja (lemari arsip lantai 3 dan 4 dikeluarkan dahulu). & \\
\hline 2. & Mobilisasi alat dan bahan, penyiapan FRP yang digunakan untuk melapis pelat, dan sika. & \multirow{2}{*}{ Kurang dari 1 hari } \\
\hline 3. & & \\
\hline 4. & Rekatkan FRP pada pelat secara perlahan menggunakan perekat epoxy. & \\
\hline
\end{tabular}

\section{Tabel 4.9 Metode Pekerjaan dan Lama Waktu Pengerjaan Perkuatan Pelat Lantai} dengan IWF

\begin{tabular}{|c|c|c|}
\hline No. & Langkah Kerja & Lama p engerjaan \\
\hline 1. & $\begin{array}{l}\text { Pembersihan lahan kerja (lemari arsip lantai } 3 \text { dan } 4 \text { dikeluarkan } \\
\text { dahulu). }\end{array}$ & \multirow{4}{*}{2 Hari } \\
\hline 2. & Mobilisasi Alat dan bahan & \\
\hline 3. & Pemasangan pelat untuk sambungan TWF dengan Balok Beton & \\
\hline 4. & Pemasangan $\Gamma \mathrm{WF}$ & \\
\hline 5. & Setelah 1x24jam, lemari arsip disimpan kembali ketempat semula. & - \\
\hline \multicolumn{3}{|c|}{${ }^{*}$ Keterangan } \\
\hline \multicolumn{3}{|c|}{ 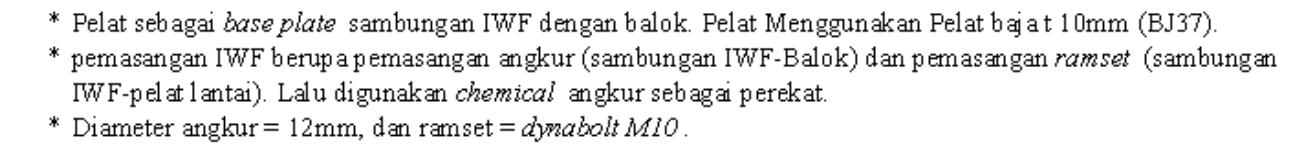 } \\
\hline
\end{tabular}

Dari hasil perbandingan biaya dan waktu pekerjaan, perkiraan waktu pekerjaan tidak terlalu beda jauh. Jika pekerjaan dalam jumlah banyak, tentu akan terlihat perbedaan lama waktu pekerjaan. Perkuatan dengan FRP mempunyai metode pelaksanaan lebih mudah dan waktu lebih cepat, tetapi untuk perkuatan FRP model satu, dan dua memiliki total biaya yang dikeluarkan lebih besar dibandingkan dengan perkuatan menggunakan FRP model tiga dan IWF.

\section{SIMPULAN DAN SARAN}

\section{Simpulan}

Hasil analisis dengan menggunakan metode MEH dengan software Autodesk Nastran In-cad 2016, dan analisis biaya perkuatan pelat lantai maka didapatkan:

1. Berdasarkan displacement, perkuatan pelat dengan FRP model satu lebih kecil dibandingan dengan FRP model dua dan tiga, dengan displacement sebesar $0,2067 \mathrm{~mm}$;

2. Displacement perkuatan dengan balok IWF adalah $0,781 \mathrm{~mm}$; 
3. Berdasarkan tegangan maksimum pada pelat lantai, perkuatan FRP model tiga lebih baik dibandingkan dengan FRP model satu, dan dua, dengan tegangan sebesar $3,896 \mathrm{MPa}$;

4. Tegangan maksimum pada pelat lantai dengan perkuatan FRP adalah 3,4891MPa;

5. Berdasarkan tegangan pada pelat lantai, perkuatan pelat dengan FRP model satu, dan dua lebih kecil dibandingan dengan perkuatan FRP model tiga dan balok IWF;

6. Berdasarkan tegangan maksimum pada tulangan baja pelat lantai, perkuatan FRP model tiga lebih baik dibandingkan dengan FRP model satu, dan dua, dengan tegangan sebesar 1,4767MPa;

7. Tegangan maksimum pada tulangan baja pelat lantai dengan perkuatan IWF adalah 2,318MPa;

8. Berdasarkan tegangan pada tulangan baja pelat lantai, perkuatan pelat dengan FRP model satu, dua, dan tiga lebih kecil dibandingan dengan perkuatan balok IWF;

9. Berdasarkan metode pelaksanaan perkuatan, perkuatan pelat dengan FRP lebih mudah, dan lebih cepat dibandingan dengan perkuatan balok IWF;

10. Berdasarkan biaya pelaksanaan perkuatan pada pelat lantai, perkuatan FRP model tiga lebih murah dibandingkan dengan FRP model satu, dan dua, dengan biaya perkuatan sebesar Rp. 1.235.850,-;

11.Biaya perkuatan menggunakan IWF adalah sebesar Rp. 1.449.432,-;

12.Berdasarkan biaya pelaksanaan perkuatan pada pelat lantai, perkuatan FRP model tiga lebih murah dibandingkan dengan perkuatan IWF;

13. Berdasarkan hasil analisis, metode pelaksanaan, lama waktu pekerjaan dan biaya perkuatan, perkuatan FRP model tiga paling baik.

\section{Saran}

Dalam melakukan perkuatan pelat lantai, harus mempertimbangkan antara hasil analisis, biaya, dan lama waktu pekerjaan perkuatan. Memilih perkuatan bukan saja dari hasil analisis, tetapi harus mempertimbangkan metode pelaksanaan yang paling baik pada tempat dilakukannya pelaksanaan perkuatan, waktu lama pekerjaan yang dibutuhkan, dan biaya yang dimiliki untuk melakukan perkuatan tersebut.

Perbandingan Analisis Perkuatan Struktur Pelat Dengan Metode Elemen Hingga 


\section{DAFTAR PUSTAKA}

1. American Concrete Institute, 2002, Guide for the Design and Construction of Externally Bonded FRP Systems for Strengthening Concrete Structures (ACI 440.2R-02): Reported by ACI Committee 440, ACI Committee 440

2. Andriani, N., 2011, Penanggulangan Kerusakan Under Reinforced Pada Lantai Jembatan Siphon, Retrieved Agustus 15, 2016, from:

3. http://noviandrianicivil.blogspot.co.id/2012/02/penanggulangan-kerusakanunder.html.

4. Asroni, A., 2010, Balok dan Pelat Beton Bertulang, Yogyakarta: Graha Ilmu.

5. Bangun, M., 2011, Metode Elemen Hingga Pada Struktur, Retrieved November 24 2016, from:

6. http://repository.usu.ac.id/bitstream/123456789/30280/4/Chapter\%20II.pdf.

7. Basri, T. H., 2014, Studi Eksperimental Penggunaan FRP (Fiber Reinforced Polymer) Terhadap Perkuatan Kolom Beton Bertulang, Bandung.

8. BMKG, 2014, Gempa Bumi, Retrieved Agustus 24, 2016, from: http://www.bmkg.go.id/BMKG_Pusat/Gempabumi Tsunami/Gempabumi.bmkg.

9. Dipohusodo, I., 1993, StrukturBetonBertulang, Jakarta: Penerbit Gramedia.

10. Garuda, P.G., TT, Product Catalogue, Retrieved November 19 2016, from:

11. http://www.gunungsteel.com/steel/images/stories/file/GRD-NewCatalogue.pdf.

12. Hardjoe, 2014, Struktur Atas (Upper Structure) dan Struktur Bawah (Lower Structure), Retrieved Agustus 15, 2016, from:

13. http://tanpawaton.blogspot.co.id/2014/03/struktur-atas-upper-structure-dan.html.

14. Imagebali, 2016, Beberapa Penyebab Kerusakan Bangunan dan Cara Mengatasinya, Retrieved November 16, 2016, from:

15. http://imagebali.net/detail-artikel/1050-beberapa-penyebab-kerusakan-bangunandan-cara-mengatasinya.php.

16. Imran, S., dkk., 2014, Perencanaan Dasar Struktur Beton Bertulang, Bandung: Penerbit ITB.

17. Isneini, M., 2009, Kerusakan dan Perkuatan Struktur Beton Bertulang, Retrieved Agustus 24,2016, from:

18. http://ft-sipil.unila.ac.id/ejournals/index.php/jrekayasa/article/download/25/28.

19. McCormac, J.C., 2003, Desain Beton Bertulang, Jakarta: Penerbit Erlangga.

20. Mulyono, D., 2014, Pengertian Konstruksi Bangunan, Retrieved Agustus 10, 2016, from: 
21. http://struktursivil12.blogspot.co.id/2014/03/pengertian-konstruksibangunan.html.

22. Nawy, E.G., 1990, Beton Bertulang Suatu Pendekatan Dasar, Bandung: Penerbit: PT.Eresco.

23. Nur, O.F., 2009, Analisa Pengaruh Penambahan Tulangan Tekan Terhadap Daktilitas Kurvatur Balok Beton Bertulang, Retrieved November 24 2016, from:

24. http://jrs.ft.unand.ac.id/index.php/jrs/article/download/v5-n1-nur/63.

25. Rezady, D., dkk., 2003, Concrete Repair and Maintenance, Jakarta: Penerbit Yayasan John Hi-Tech Idetama.

26. Setiawan, A., 2013, Perencanaan Struktur Baja dengan Metode LRFD, Jakarta: Penerbit Erlangga.

27. Setiawan, E., 2016, Kamus Besar Bahasa Indonesia, Retrieved November 18 2016, from:

28. http://kbbi.web.id/.

29. Siburian, S., 2010, Tanpa Judul, Retrieved November 16, 2016, from:

30. http://repository.usu.ac.id/bitstream/123456789/19296/4/Chapter\%20I.pdf.

31. SNI 2847:2013, 2013, Persyaratan Beton Struktural untuk Bangunan Gedung, Jakarta: Badan Standardisasi Nasional.

32. Tarigan, I.A., 2014, Autodesk Tawarkan Nastran Baru Berbasis Cloud, Retrieved November 17, 2016, from:

33. http://teknologi.metrotvnews.com/read/2014/08/13/277086/autodesk-tawarkannastran-baru-berbasis-cloud. 